\title{
UNION REGULATIONS ON PASSENGER RIGHTS IN CASE OF FLIGHT CANCELLATION, REFUSAL AT BOARDING OR LONG DELAY OF FLIGHTS
}

\author{
E. -N. VÂLCU
}

\author{
ELISE NICOLETA VÂLCU \\ University of Pitești, Pitești, Romania \\ *Correspondence: Elise Nicoleta Vâlcu, University of Pitești, str. Târgu din Vale, \\ no. 1, Pitești, România \\ E-mail: elisevalcu@yahoo.com
}

\section{ABSTRACT:}

The European Union is a "supranational governance" structured by its well-defined institutions. The decision-making triangle formed by the Commission, the Parliament and the Council legislate in agreement or consultation, covering the whole picture of policies developed at EU level and implemented at Member State level. Among the most important developed policies, it is necessary to mention the freedom of movement of the Union nationals, freedom of movement of goods and services, judicial cooperation in criminal matters, etc. Freedom of movement implies a series of segmental rights, such as the right to temporary or permanent residence, the right to work, to travel and study, etc. The Union law system identifies legal instruments to regulate the rights of passengers traveling within the Union, from the Union to a third country, or arriving in the territory of a Member State irrespective of the type of transport, air, rail, water or road.

At present, in the field of air transport we identify Regulation no. 261/2004 on the right to compensation and assistance to passengers in the event of refusal of boarding and cancellation or long delay of flights, which is part of a comprehensive package of legislation aimed at protecting consumers in general across the European Union.

KEY WORDS: refusal to board, cancel flight, trip, flight operator, booking.

\section{INTRODUCTION}

Regulation No 261/2004 ${ }^{1}$ of establishing common rules on compensation and assistance to passengers in the event of denied boarding and of cancellation or long delay of flights originated from the need for a uniform interpretation of the relevant Union legislation in the matter, a Union standard of protection for citizens.

From the legislative package in this field, together with the above-mentioned Union Regulation and subject to the analysis in the present document, the Regulation (EC) no. No 2027/97 of the Council of 9 October 1997 on air carrier liability in the event of accidents $e^{2}$, as amended by Regulation (EC) (EC) No 889/2002 of the European Parliament and of the Council $^{3}$ and the Convention for the Unification of Certain Rules Relating to International Carriage by Air, also called the Montreal ${ }^{4}$ Convention. 889/2002 is the EU legislative

\footnotetext{
${ }^{1}$ Regulation (EC) No 261/2004 of the European Parliament and of the Council of 11 February 2004 establishing common rules on compensation and assistance to passengers in the event of denied boarding and of cancellation or long delay of flights, and repealing Regulation (EEC) 295/91.

2 JO L 285, 17.10.1997.

${ }^{3} \mathrm{~J} O \mathrm{~L}$ L140 30.05.2002

${ }^{4}$ The Convention for the Unification of Certain Rules for International Carriage by Air, known as the "Montreal Convention", was signed in Montreal on 28 May 1999. The European Union is a contracting party to the Convention and some of its provisions have been transposed into legislation Union by Regulation (EC) No. (EC)
} 
UNION REGULATIONS ON PASSENGER RIGHTS IN CASE OF FLIGHT

CANCELLATION, REFUSAL AT BOARDING OR LONG DELAY OF FLIGHTS

instrument serving a double purpose: on the one hand, the alignment of EU legislation on the liability of air carriers to passengers and their luggage to the provisions of the Montreal Convention, to which the EU is one of the contracting parties, and, on the other hand, extending the application of the Convention rules to air services offered in the territory of a Member State. They are added to Directive (EU) 2015/2302 on Travel Packages and Associated Travel Formulas, which became fully applicable on 1 July 2018.

\section{IDENTIFYING AND ANALYZING THE EVENTS FROM WHICH AIR PASSENGERS' RIGHTS ARE RECOGNIZED UNDER REGULATION (EC) NO. 261/2004}

As a first, step approach, it is necessary to identify the categories of beneficiaries for which the provisions of this rule are incidental.

a) Passenger-beneficiaries categories. Beneficiaries of the rights recognized and guaranteed by this normative act are:

i) passengers departing from an airport located in the territory of a Member State;

ii) passengers departing from an airport located in a third country to an airport located in the territory of a Member State, except in cases where they have received allowances or compensation and have received assistance in that third country, provided that they have a confirmed reservation for that flight or, if the time is not indicated, no later than 45 minutes before the published departure time ${ }^{5}$. Article 3 (1) (a) of the Regulation does not apply to a return journey where passengers originally departing from an airport located in the territory of a Member State return to that airport on a flight operated by a non-EU carrier departing from an airport located in a third country.

iii) passengers holding tickets issued by an air carrier or tour operator under a customer loyalty program or other commercial program.

The provisions of the Regulation do not apply:

1) in cases where a package of tourist services is canceled for reasons other than cancellation of the flight ${ }^{6}$;

2) passengers traveling free of charge or at a reduced rate which is not available directly or indirectly to the public, such as special gifts offered by air carriers to their own staff;

3) Multimodal journeys involving multiple modes of transport under a single transport contract.

b) The cancellation of a flight constitutes a first event giving rise to the rights recognized in Articles 7, 8 and 9 of this Regulation.

In order to make a meaningful analysis of the consequences of canceling a flight, it is necessary to clarify the term "flight". Thus, the concept of "flight" is not defined in the introductory part of the union norm, it was subsequently clarified by the CJEU, the Union Court ruling in this respect. In particular, in Case C-173/07, Emirates Airlines, ECLI: EU: C: 2008, the Court found that a voyage involving a take-off flight and a return flight cannot be regarded as a single flight. The concept of "flight" within the meaning of the Regulation should be interpreted as consisting essentially of a single "unit" even if the departure and return flight are subject to a single reservation, which is intended to leave an airport outside the EU (for example, in a third country) and traveling to the EU if the flight is performed by an air carrier licensed in an EU Member State (EU carrier).

Article 2 (1) of the Regulation defines the "cancellation" as the non-completion of a previously planned flight for which at least one seat has been reserved. Cancellation takes

\footnotetext{
No 2027/97, as amended by Regulation (EC) No. 889/2002. These rules form part of a set of measures aimed at protecting the rights of air passengers in the European Union, together with Regulation (EC) 261/2004.

${ }^{5}$ Article 3 paragraph 2 letter a of Regulation no. 261/2004

${ }^{6}$ art. 3 paragraph 6 of the Regulation; see also Directive (EU) 2015/2302 on package travel and associated travel formulas
} 


\section{Elise Nicoleta Vâlcu}

place in principle when the initial flight plan is abandoned and the passengers of that flight join the passengers on a flight that was also planned, but independent of the initial flight. Moreover, in Case C-83/10 Sousa Rodríguez and Others ${ }^{7}$, the CJEU has ruled that there must be no express decision by the carrier to cancel that flight for the purpose of the actual cancellation. Similarly, in Joined Cases C-402/07 and C-432/07 Sturgeon and Others ${ }^{8}$, the CJEU explains that not always recovering luggage or obtaining a new boarding card is a decisive factor in determining that that flight has been cancelled, thus taking as the only criterion the " objective characteristics of the flight ".

Furthermore, a conceptual differentiation must be made between the notions of "canceling" and "delaying" of a flight. Jurisprudential views are varied, however, we may note that we are in the presence of a "delay" whenever we notice that the flight number does not change irrespective of the time elapsed between the initial display of the race and the actual flight. However, no assertion of the above-mentioned opinion per a contrario is always a reason for canceling the flight. Thus we come to the conclusion that, for example, a flight may face such a delay that the take-off takes place the day after the scheduled flight and is therefore assigned an annotated flight number (for example, AA $4321 \mathrm{X}$ instead of AA 4321) to differentiate the flight with the same number on that subsequent day. However, in this case the flight could be considered a delayed flight, not canceled.

In practice, the situation is also identified in which an aircraft departs, but for some reason is subsequently forced to return to the departure airport and the passengers of that aircraft are transferred to other flights. We believe that such a situation can be considered the cause of "cancellation" within the meaning of Article 2 (1) of the Regulation. Thus, the fact that the take-off took place, but the airplane subsequently returned to the departure airport without having reached the destination specified in the itinerary, has the effect that the flight, as initially envisaged, cannot be considered.

c) Refusal to board. The concept of 'refusal of boarding' refers, on the one hand, to cases of overbooking, and to refusing to board for operational reasons. The situation where a passenger traveling with a pet cannot board because he does not have the necessary documentation for a pet trip can not constitute a refusal to board.

d) Flight delay. Under Article 6 of the Regulation, "flight delay" means any of the cases where an air carrier anticipates a possible delay of a flight beyond the scheduled time of departure as follows:

- two hours for flights over 1500 kilometers or less;

- three hours or more for all intra-Community flights of over 1500 kilometers and any other flights between 1500 and 3500 kilometers

The CJEU, in its judgment in Joined Cases C-402/07 and C-432/07 Sturgeon and Others ${ }^{9}$, held that a delay of at least three hours on arrival confers the same rights in compensation as cancellation. With regard to 'time of arrival', the Court clarified the meaning of the phrase in its judgment in Case C-452/13 Germanwings, ECLI: EU ${ }^{10}$, in the sense that the notion of 'arrival time' used to determine the length of the delay suffered by passengers flight if arrival is delayed corresponds to the moment when at least one of the aircraft doors opens, assuming that at that time passengers are allowed to leave the aircraft.

\section{PASSENGer Rights IN CASE OF CANCEllation OF A Flight, BOARDING REFUSAL OR DELAY.}

\footnotetext{
${ }^{7}$ Case C-83/10, Sousa Rodríguez and Others, ECLI: EU: C: 2011: 652

${ }^{8}$ Joined Cases C-402/07 and C-432/07, Sturgeon and Others, ECLI: EU: C: 2009: 716

${ }^{9}$ Joined Cases C-402/7 and C-432/07, Sturgeon and Others, ECLI: EU: C: 2009: 716

10 Case C-452/13, Germanwings, ECLI: EU: C: 2014: 2141
} 
UNION REGULATIONS ON PASSENGER RIGHTS IN CASE OF FLIGHT

CANCELLATION, REFUSAL AT BOARDING OR LONG DELAY OF FLIGHTS

Both cancellation of a flight and refusal of boarding against the passenger's wishes or delay shall entitle him to reimbursement, re-routing or a new reservation at a later date as defined in Article 8 of the Regulation; the right to "service" as defined in Article 9 and, in accordance with Article 5 (1) (c), the right to "compensation" as defined in Article 7.

Right to compensation. According to Article 7, in the event of cancellation of a flight and in case of refusal of boarding against the passenger's will or delay, passengers are compensated in the amount of:

a) EUR 250 for all flights of 1500 kilometers or less;

b) EUR 400 for all intra-Community flights of more than 1500 kilometers and for all flights between 1500 and 3500 kilometers;

c) EUR 600 for all flights not covered by (a) or (b).

As regards the cancellation of a flight, according to the principle underlying Article 5 (1) (c), compensation must be paid if the passenger has not been informed of the cancellation sufficiently in advance. However, the carrier shall not be obliged to pay compensation if he is able to prove, in accordance with Article 5 (3), that the cancellation is due to extraordinary circumstances which could not have been avoided even if all reasonable measures had been taken.

In order to be exempted from the payment of compensation, the carrier must at the same time prove:

- existence and link between extraordinary circumstances and delay or cancellation;;

- the delay or cancellation could not be avoided even though the carrier took all reasonable steps.

In particular, for a better understanding, we can exemplify Case C-549/07, WallentinHermann ECLI: EU ${ }^{11}$, in which the CJEU clarified to what extent a "technical problem" that occurs during aircraft maintenance or is caused by the lack of maintenance of an aircraft cannot be considered an 'extraordinary circumstance'. Thus, the Court considers that if an unexpected technical problem is not due to deficient maintenance and is not detected during routine maintenance, such a problem does not fall within the definition of "extraordinary circumstances" when is inherent in the normal exercise of the air carrier's activity. It is a "technical problem" and implicitly qualifies as an extraordinary circumstance, the damage caused to the aircraft by acts of terrorism.

As regards compensation for canceled flights, we specify that claims for compensation are not eligible if the air carrier has notified the passenger at least 14 days in advance.

The Regulation provides that in return for compensation for cancellation of a flight, the airline may offer an alternate flight that must meet certain conditions, namely:

a) if the notification took place less than 14 days but more than 7 days, an alternative flight can be offered which departs no more than 2 hours before and reaches less than 4 hours after the initial flight;

b) if the notification took place less than 7 days, an alternative flight can be offered departing no more than 1 hour before and arriving less than 2 hours after the initial flight.

Right to service in the event of refusal of boarding, cancellation or delay in departure. The right to service exists only as long as passengers have to wait for the redirection, under comparable transport conditions, to the final destination at the earliest possible opportunity. Serving involves the right of passengers to be offered free of charge: a) meals and refreshments directly proportional to the waiting time, b) hotel accommodation if one or more nights of stay are required or an additional stay than that provided by the passenger; c) transport between the airport and the place of accommodation (hotel or other).

\footnotetext{
${ }^{11}$ Case C-549/07, Wallentin-Hermann, ECLI: EU: C: 2008: 771
} 


\section{Elise Nicoleta Vâlcu}

The service delivery must be assessed on a case-by-case basis, taking into account the needs of the passengers and "directly proportional to the waiting time", in concrete terms, meaning the estimated duration of the delay and the time of the day (or night) which is the delay. Passengers should therefore not be allowed to take the necessary measures themselves, such as finding and paying accommodation or food, effective air carriers being forced to actively serve the service.

If passengers refuse reasonable accommodation offered by the air carrier pursuant to Article 9 and deal personally with the necessary arrangements, the air carrier shall not be obliged to reimburse the costs incurred by the passengers, except where otherwise agreed between the parties, only up to the amount of "reasonable offer". Passengers can sue the costs occasionally, so they have to keep all receipts and bills for the expenses they incur.

However, according to recital 18 of the Regulation, service may be limited or refused if its performance could cause additional delay to passengers waiting for an alternate or delayed flight. If a flight is delayed late at night but is expected to leave in just a few hours and delays in this case could be much higher if passengers had to be sent to the hotel and brought back to the airport in the middle of the night, should be able to refuse to grant service.

Right to reimbursement. Cancellation of a flight, refusal to board or delay flights provides passengers the opportunity to request reimbursement within seven days of the full cost of the ticket at the purchase price for the unused part or parts of the trip and for the part or parts already made, where flight becomes useless in relation to the passenger's initial travel plan

\section{PROCEDURE FOR SETTLING DISPUTES BETWEEN AIR CARRIERS AND PASSENGERS ON LOW-VALUE APPLICATIONS}

The passenger in his / her capacity as a plaintiff may request compensation for the above mentioned reasons, the jurisdiction of which is the court having its place of departure or arrival, according to the contract of carriage. In accordance with Article 4 (1) of the Brussels $\mathrm{I}^{12}$ Regulation, passengers also retain the option of bringing the matter before the courts of the State in which the defendant (air carrier) is based. The Regulation does not set deadlines for bringing actions before the national courts. This issue is a matter for the national legislation of each Member State on prescription, so the deadlines may vary between Member States.

In order to resolve disputes between passengers and the flight operator, the European Small Claims Procedure may be used to obtain compensation for a maximum amount of EUR 5,000 .

In the case of this type of action, the request for a summons takes on a standard form which the applicant completes. Following registration at the Registry, the court may notify the complainant of his or her application if information is missing. The petition for legal action once declared admissible is communicated to the party, who has 30 days to answer. After 30 days have elapsed since the time period provided by the defendant to respond to the complainant, the court may request that the evidence be filled in, as the case may be, with the documents or hearings of the parties.

The decision of the court not contested by the defendant will be enforced through the order for payment procedure ${ }^{13}$ which is a simplified procedure for the recovery of crossborder pecuniary claims not claimed by the party. The procedure is initiated by the claimant by completing a standard form in which the nature and amount of the claim are inserted. The court shall examine the application and if the form is complete and correctly completed, it

\footnotetext{
12 Council Regulation (EC) Regulation (EU) No 1215/2012 of the European Parliament and of the Council ("Brussels I Regulation")

${ }^{13}$ see the provisions of Regulation No 1896/2006 of the Parliament and of the Council of 12 December 2006 setting up an European Order for Payments Procedure.
} 
UNION REGULATIONS ON PASSENGER RIGHTS IN CASE OF FLIGHT

CANCELLATION, REFUSAL AT BOARDING OR LONG DELAY OF FLIGHTS

shall issue the European Payments Notice within 30 days. The order for Payment is notified to the petitioner, who has two solutions, either pays the amount mentioned in the summons as a claimant, or disputes the summons having a 30-day term in which to oppose it. If the defendant does not oppose, the payment order shall automatically become enforceable and shall be transmitted to the executing authority in the executing Member State. Execution is to be done according to the national procedures of the EU Member State in which they have their execution.

\section{CONCLUSIONS}

The Union norm, deducted from the analysis, regulates a set of rights related to exhaustively determined situations with the immediate aim of improving the standards of protection, enhancing the rights of passengers and ensuring the performance of the activities of air carriers in harmonized conditions on a liberalized air market.

\section{BIBLIOGRAPHY}

1. Regulation (EC) No. No 261/2004 of the European Parliament and of the Council of 11 February 2004 establishing common rules on compensation and assistance to passengers in the event of denied boarding and of cancellation or long delay of flights

2. Council Regulation (EC) No 889/2002 of the European Parliament and of the Council on the liability of carriers of aircraft in the event of accidents.

3. Regulation 1896/2006 of the European Parliament and of the Council of 12 December 2006 setting up an European Order for Payments Procedure

4. Regulation (EC) no. Regulation (EU) No 1215/2012 of the European Parliament and of the Council ("Brussels I Regulation")

5. Directive (EU) 2015/2302 on package travel and associated travel formulas

6. Case C-173/07, Emirates Airlines, ECLI: EU: C: 2008

7. Case C-83/10, Sousa Rodríguez and Others, ECLI: EU: C: 2011: 652

8. Joined Cases C-402/07 and C-432/07, Sturgeon and Others, ECLI: EU: C: 2009: 716

9. Case C-549/07, Wallentin-Hermann, ECLI: EU: C: 2008: 771 